\title{
Procedural Effects of Environment Impact Assessment on Controlling Natural Disaster (Landslides and Flashflood) Based on Environmental Degradation from Development in Malaysia
}

\author{
Syabiha Shith, Nor Azam Ramli, Muhammad Rizal Razman, Amni Umirah Mohamad Nazir, Nazatul \\ Syadia Zainordin, and Wesam Al Madhoun
}

\begin{abstract}
Environmental impact assessment (EIA) is a preemptive tool used by engineers, environmental consultants and planners to avoid the most likely adverse consequences of development projects. As a planning tool, EIA should curb the harmful effects from all stages of a project lifecycle. Landslides and flash floods are the most common problems faced by Malaysians almost yearly due to rapid development, especially that involving modification of watercourses, clearing of land and projects on hill slopes. Despite such issues, existing legislation and new guidelines have been enacted by the Malaysian government and must be followed by any proposing project team before starting development projects. The Department may have accepted an EIA report of the project. Still, several developments may have neglected the guidelines, especially during construction involving earthworks and exposure of the surrounding environment, place and people to a high risk of disaster caused by mishaps and accidents. The incidence of landslides and flash floods as reported in newspapers, journals, reports and books since 1919 is explored in this study to determine the details of the losses and locations. Despite the enactment of the new EIA law, landslides and flash floods continue to occur. This situation justifies the need to revise the approach based on sizes and include other factors, namely, the risk indices for disaster to happen and the effectiveness of EIA in reducing disaster risks in projects.
\end{abstract}

Index Terms-Development projects, intense rainfall, prevention, risks, slope failure, soil erosion.

\section{INTRODUCTION}

Environmental impact assessment (EIA) is an operational procedure to prevent, reduce and control the adverse effects

Manuscript received March 12, 2021; revised June 8, 2021. This study was funded by EACAR Alumni Personal Fund, Universiti Sains Malaysia, personal fund.

Syabiha Shith and Nor Azam Ramli are with the Environmental Assessment and Clean Air Research, School of Civil Engineering, Engineering Campus, Universiti Sains Malaysia, 14300, Nibong Tebal, Penang, Malaysia (e-mail: syabihashith@gmail.com, ceazam@usm.my).

Muhammad Rizal Razman is with the Pusat Penyelidikan Sains \& Governans Kelestarian (SGK), Institut Alam Sekitar \& Pembangunan (LESTARI), Universiti Kebangsaan Malaysia, 43600 UKM, Bangi Selangor Darul Ehsan, Malaysia (e-mail: mrizal@ukm.edu.my).

Amni Umirah Mohamad Nazir is with the Faculty of Earth Science, Universiti Malaysia Kelantan Kampus Jeli, Locked Bag No. 100, 17600, Jeli, Kelantan, Malaysia (e-mail: nurummie274@gmail.com).

Nazatul Syadia Zainordin is with the Faculty of Environmental Studies, Universiti Putra Malaysia, 43400 UPM Serdang, Selangor Darul Ehsan, Malaysia (e-mail: nazatulsyadia@upm.edu.my).

Wesam Al Madhoun is with the Micro-Pollutant Research Centre (MPRC), Faculty of Civil Engineering and Built Environment, Universiti Tun Hussein Onn Malaysia, 86400 Parit Raja, Johor, Malaysia (e-mail: wesam@uthm.edu.my). or harm to the environment of proposed development activity early during their planning stage. The project proponents aim to draw best practicable environment options from the assessment, include them in the EIA report with details of mitigation measures needed before the approval and implementation of a project [1]-[4]. Activities that lead to environmental problems - whether in air, in water or on lands such as deforestation, pollution of water and water catchments, destruction of endangered fauna and flora, failures of soil, landslides, sedimentation and downstream flooding - may result in considerable environmental degradation [5], [6]. This environmental degradation combined with monetary and in extreme cases involving casualties could result from frequent, intensified landslides and flash floods 'enhanced' by soil erosion and drainage system sedimentation. The development of substantial projects causes most of these incidents without proper mitigation measures implemented [5], [7]. While environmental management covers dynamic approaches, sustainable development, the preventive aspect, the 'polluter pays' principle and the need for people to reduce risk and be more flexible [8], in some instances, these principles are not fully implemented in protecting the environment.

In Malaysia, the Environmental Quality (Prescribed Activities, EIA) Order 2015 (EQPAEIAO2015) came into force on 5th August 2015. This new order, which has two schedules with 38 listed projects, replaced the Environmental Quality (Prescribed Activities, EIA) Order 1987 (EQPAEIAO1987) enacted on 30th September 1987 that only listed 19 projects. Both orders have sizes, areas and quantums for prescribed activities in both schedules. Nevertheless, specific scientific reason and technical reasons for such limits are absent. All projects falling within those listed should carry out EIA and submit EIA reports for pre-approval before granting planning approval. EIA is the primary planning instrument that should 'protect' humans and nature from vulnerability to development projects' influence.

Emphasised at project levels resulted in, master plans, programmes, and policies are not subject to environmental assessment before their implementations. The best practice in environmental protection should evaluate the most probable risks arising from all development activities at all project stages [9], including master plans and programmes and policies. An EIA report is a vital part of a project's development. Through the statement, the project proponent makes a legal pledge of commitment to implement pollution 
prevention and mitigation measures (P2M2), and reduce the adverse effects on the environment [2]. Moreover, an EIA report is a considerable input to decision making by enabling the project's approval authority to make an informed decision on whether a proposed project can be approved for implementation. EQPAEIAO2015 is better than EQPAEIAO1987 in terms of its legal commitment from proponent and clarity in approval processes.

In addition to the United Nations International Strategy for Disaster Reduction and Hyogo Framework for Action, the development-induced disaster risks should also be considered in the EIA report [10], to prevent disasters. The effectiveness of the EIA report currently or recently submitted in addressing the disaster risks of development projects has not been widely studied. Albeit regulated, such developments, especially during land clearing and construction phases, pose dangers of environmental disasters, i.e. flash floods and landslides, to the public. Both disaster types threaten the wellbeing of life and property of nearby conurbations. Understanding the integration of disaster risks in EIA processes still open for enhancement, but the incidences and reported causes from historical data must be studied. In the EIA process, all government agencies are responsible for preparing a detailed statement of the impacts, effects, alternatives and other matters and the recommended actions that will secure the quality of the human environment. The public should receive the circulated comment by other agencies or particular expertise for their justification. As a result, EIA will act as an administrative reform to force government agencies to alert with the public concern and directly been an effective process for a better environment. Hence, this study reviewed the temporal incidents and the factors which could have caused landslide and flash flood cases in Malaysia. They are reviewed, listed and briefly discussed in tabular forms.

\section{REgulations AND REgUlatory AgENCIES RESPONSIBLE FOR CURBING LANDSLIDES AND FLASH FLOODS}

Examples of existing legislation and guidelines related to landslides and flash floods in Malaysia are listed in Table I. The general legal guidance framework for major Malaysian development comprises the EQPAEIAO2015, Local Government Act 1976, National Forestry Act 1984, Jabatan Kerja Raya Slope Design Guidelines 2009, and Street, Drainage and Building Act 1974 (Act 133). Besides, local levels establish guidelines to control landslides, i.e. Federal Territory Planning Act 1982, Selangor Guidelines 2010, Kuala Lumpur Guidelines 2010 and Safety Guidelines for Hillside Development Pulau Pinang 2012.

TABLE I: REGULATIONS AND AGENCIES RELATED TO LANDSLIDES AND FLASH FLOODS

\begin{tabular}{|c|c|c|}
\hline \multicolumn{3}{|c|}{ FLASH FLOODS } \\
\hline Management & Statute & Agencies \\
\hline \multirow{6}{*}{$\begin{array}{l}\text { Water and } \\
\text { river } \\
\text { protection }\end{array}$} & Water Act 1920 & Water Supply \\
\hline & & Department \\
\hline & $\begin{array}{l}\text { Environmental Quality Act } \\
1974\end{array}$ & $\begin{array}{l}\text { Department } \\
\text { Environment }\end{array}$ \\
\hline & Local Government Act of 1976 & Local Authority \\
\hline & National Forestry Act 1984 & Forestry Department \\
\hline & $\begin{array}{l}\text { Street, Drainage and Building } \\
\text { Act } 1974 \text { (Act 133) }\end{array}$ & Local/State Authority \\
\hline
\end{tabular}

\begin{tabular}{|c|c|c|}
\hline & \begin{tabular}{lr} 
Urban & \multicolumn{2}{c}{ Stormwater } \\
Management & Manual 2000 \\
(MSMA) & \\
\end{tabular} & $\begin{array}{l}\text { Department } \\
\text { Irrigation } \\
\text { Drainage } \\
\end{array}$ \\
\hline \multirow[t]{5}{*}{ Land and soil } & Land Conservation Act of 1960 & Local Authority \\
\hline & National Land Code 1965 & Land Office \\
\hline & $\begin{array}{l}\text { Town and Country Planning } \\
\text { Act } 1976\end{array}$ & $\begin{array}{l}\text { Town and Country } \\
\text { Planning Department }\end{array}$ \\
\hline & Roadside Drain & $\begin{array}{l}\text { Public } \\
\text { Department }\end{array}$ \\
\hline & $\begin{array}{l}\text { Guideline for Erosion and } \\
\text { Sediment Control } 2010\end{array}$ & $\begin{array}{l}\text { Department } \\
\text { Irrigation } \\
\text { Drainage } \\
\end{array}$ \\
\hline \multirow[t]{13}{*}{$\begin{array}{l}\text { Hill site } \\
\text { development }\end{array}$} & $\begin{array}{l}\text { Town and Country Planning } \\
1976 \text { (Act 172) }\end{array}$ & $\begin{array}{l}\text { Urban and Rural } \\
\text { Planning } \\
\text { Department }\end{array}$ \\
\hline & $\begin{array}{l}\text { Environmental Quality Act } \\
1974\end{array}$ & $\begin{array}{l}\text { Department } \\
\text { Environment }\end{array}$ \\
\hline & National Physical Plan 2005 & Local Authority \\
\hline & $\begin{array}{l}\text { High Land Development } \\
\text { Guidelines } 2005\end{array}$ & MASTECC \\
\hline & $\begin{array}{l}\text { Federal Territory Planning Act } \\
1982 \text { (FTPA) }\end{array}$ & $\begin{array}{l}\text { Ministry of Federal } \\
\text { Territories }\end{array}$ \\
\hline & $\begin{array}{l}\text { Draft Guidelines for the } \\
\text { Conservation } \\
\text { Development of Environmental } \\
\text { Sensitive Area and its } \\
\text { Surrounding Area, 2005 }\end{array}$ & \\
\hline & $\begin{array}{l}\text { Development and Planning } \\
\text { Guidelines for Hilly and High } \\
\text { land Area }\end{array}$ & $\begin{array}{l}\text { Ministry of Housing } \\
\text { and } \\
\text { Government, } 2009\end{array}$ \\
\hline & $\begin{array}{l}\text { Garis Panduan Pembangunan } \\
\text { Di Kawasan Tanah Tinggi } \\
\text { (GPPDKTT) }\end{array}$ & MASTECC \\
\hline & $\begin{array}{l}\text { Garis Panduan Pembangunan } \\
\text { Di Kawasan Tanah Tinggi bagi } \\
\text { Wilayah Persekutuan Kuala } \\
\text { Lumpur (GPWPKL) }\end{array}$ & $\begin{array}{l}\text { Ministry of Federal } \\
\text { Territories }\end{array}$ \\
\hline & $\begin{array}{l}\text { Development and Planning } \\
\text { Guidelines for Hilly and High } \\
\text { land Area, State of Selangor } \\
2010\end{array}$ & State of Selangor \\
\hline & Slope Design Guideline 2009 & $\begin{array}{l}\text { Public } \\
\text { Department }\end{array}$ \\
\hline & $\begin{array}{l}\text { Guidelines on } \\
\text { Development } 2002\end{array}$ & $\begin{array}{l}\text { Minerals } \\
\text { Geoscience } \\
\text { Department } \\
(\mathrm{JMG})\end{array}$ \\
\hline & $\begin{array}{l}\text { Penang Guideline for Hill site } \\
\text { Development } 2012\end{array}$ & $\begin{array}{l}\text { Majlis Perbandaran } \\
\text { Pulau Pinang }\end{array}$ \\
\hline
\end{tabular}

Sources: [11]-[15]

EIA Guidelines 2016 has been used as the primary reference [2] to carry out EIA as a replacement of the 'Handbook of Environmental Impact Assessment in Malaysia' [16]. The former follows the new EQPAEIAO2015, whereas the latter represents the replaced EQPAEIAO1987. EIA has been detailed in these guidelines and the Department of Environment; Malaysia provided 32 additional guidelines/documents for EIA reference [2]. Proposed developments in Malaysia are subjected to the first and second schedule under EQPAEIAO2015 [2], [3]. Prescribed activities that could cause landslides and flash floods in Malaysia are listed in both schedules of EQPAEIAO2015. Schedule 1 lists developments in slope area (No. 13), housing (No. 16) and road (No. 20). Schedule 2 describes activities of development for slope area (No. 13). Table II compares the oldest Environmental Quality (Amendment) Act 1985 and the newest EIA Guideline 2016 used in Malaysia. 
TABLE II: REGULATIONS AND AGENCIES RELATED TO LANDSLIDES AND FLASH FLOODS

\begin{tabular}{ll}
\hline \multicolumn{1}{c}{ Pre 2016 } & \multicolumn{1}{c}{ Post-2016 } \\
\hline $\begin{array}{l}\text { Pre-submission of Report: } \\
\text { The project was divided into two }-\end{array}$ & $\begin{array}{l}\text { Pre-submission of Report: } \\
\text { The project was classified into two } \\
\text { preliminary study and detailed }\end{array}$ \\
study. & $\begin{array}{l}\text { (2) groups which were First and } \\
\text { Second Schedule. }\end{array}$ \\
\hline During submission of Report: & During submission of Report: \\
It was reviewed by special & It was reviewed by DOE Technical \\
technical panels comprising & Review Committee (Team of DOE \\
individuals from government & officers at DOE State or \\
agencies, the universities, the & Headquarters). The project that \\
private sector and & classified as Second Schedule \\
non-governmental organisations. & project was displayed for public \\
& viewing. \\
\hline Post Submission of Report: & Post Submission of Report: \\
& Need to submit EMP and presenting \\
the COA Execution Plan. \\
(EMP) after project approval. & Need to provide Compliance \\
& Monitoring (CM), Impact \\
& Monitoring (IM), Performance \\
& Monitoring (PM) and $3^{\text {rd } \text { Party }}$ \\
& Audit. \\
\hline
\end{tabular}

In 1997, the Urban and Rural Planning Department was the first authority to document hillside development in Malaysia, including planning and development in highlands regarding slopes, natural waterways and water catchment areas [17]. The Minerals and Geo-science Department Malaysia produced guidelines on hillside development in 2002, which classify slope angles into Class I, II, III and IV. Class $\mathrm{I}$ is the least severe in terms of terrain grading where slope angles are less than $15^{\circ}$, Class II is for slopes between $15^{\circ}$ and $25^{\circ}$, Class III is for slopes between $25^{\circ}$ and $35^{\circ}$, and Class IV is for gradients with the highest risk of having an angle greater than $35^{\circ}$ [18]. Numerous other guidelines and regulations are related to slope management from the following governmental and private agencies.

\section{Potential CAUSAl EFFECTS ON THE EnVIRONMENTAL}

Sensitivity and resilience control the impacts of developments on the environment. Barrow [8] defined sensitivity as the level that a given ecosystem becomes different as the effect of natural or human activities. Resilience refers to how an ecosystem can remain unchanged. It was first suggested as a measure of the potential of an ecosystem to change to a continuously evolving environment without failure [8]. Blaikie and Brookfield [19] recommended a simple categorisation of land-based sensitivity and resilience, which may be changed to apply to ecosystems in general as 1) Ecosystem with low risk and high variability. This situation happens in poor management or natural disaster and is the best ecosystem to strengthen food and other commodities. 2) Ecosystem with high risk and high durability. This adverse situation occurs rapidly but recovers well with good management. 3) Ecosystem with low sensitivity and low durability, where management and recovery to save things are challenging to carry out. 4) Ecosystem with high sensitivity and low durability. Degradation occurs rapidly with a low reaction for management and recovery. The ecosystem is better left alone, which aligns with the pollution prevention mitigating measure themes in the new EQPAEIAO2015. Two substantial consequences are landslides and flash floods.

\section{A. Landslides}

Construction activities of major projects could cause considerable adverse effects on the environment. Stages of construction are generally associated with soil disturbance due to land clearing and grading activities. When both events occur together with the tropical climate in Malaysia, this situation will lead to the generation of soil erosion that is deposited in the adjacent water bodies [5][20]. Uncontrolled construction, earth clearing activities and human activities induce the seriousness of floods from precipitation due to peak discharge and concentration-time [20].

The occurrence of many landslides and flash floods due to environmental degradation has tragic consequences. For example, many landslides have been recorded in Cameron Highlands since a century and a half ago due to land clearing and development since 1919 [21] and 1961 [20]. Elsewhere in the country, many developments have been constructed on hilly areas with multiple ranges of slopes; the steeper the hill is, the higher the risk of soil movement and slope failures. The development within areas surrounding the hillside is known to cause environmental problems such as soil erosion and landslips. These problems have been reported to cause property damage, injury and death [22].

The previous study showed that understanding high-potential landslide regions and predicting slope failure based on geotechnical and geological engineering is essential for sustainable development [22]-[25]. Human activities are one of the triggering factors and may directly affect nature. Several findings stated that $20 \%$ of landslides are caused by human interventions such as excavation on slope area or overloading/disturbance of slope balance and slope sliding [26], [27].

In Malaysia, slope failures or landslides occur during intense rainfall (total rainfall of more than $70 \mathrm{~mm}$ ) or an extended period (over one day) of average rainfall [28], [29]. Bujang et al. [30] found that the most common type of landslides is usually not more than $4 \mathrm{~m}$ in depth and occurs immediately after heavy rainfall, particularly in September to January. In Cameron Highlands, soil erosion problems were associated with high rainfall potential to erode and land-use changes [31]. Technical papers, national reports, newspapers and other sources of literature were used to gather information on historical records of landslides, as shown in Fig. 1. The historical records showed that annual landslides occurred mainly in Kuala Lumpur, Ipoh, Pulau Pinang and Cameron Highlands.

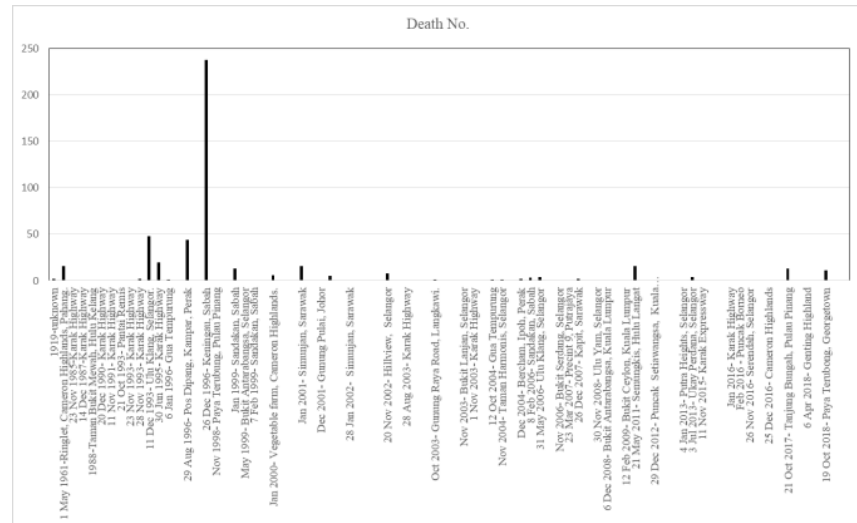

Fig. 1. Number of death from historical records of landslides in Malaysia (Source: [18], [30], [32]-[40]). 
A classic incident on the hazard of hillside development on 11th December 1993 was the collapse of Block 1 of Highland Towers in Kuala Lumpur that killed 48 people. This incidence raised the concern of many researchers towards the hazard of hillside development [18], [21], [34], [41]-[43]. Previous hill slope development guidelines have been revised for stricter compliance for developers, contractors and house owners after this incident [44]. The adequacy and effectiveness of statutory provisions and EIA report for the hill site construction and development have been re-examined with the numbers of landslides increasing yearly. The years 2017 and 2018 saw two substantial landslides in development projects in Tanjung Bungah and Paya Terubong, respectively [45], where 11 and 9 casualties were reported. The landslides resulted from continuous downpour for several days on ill-covered land and slopes. Frequencies of landslides in 10 countries including Malaysia from 2007 to 2016 are shown in Fig. 2 [46].

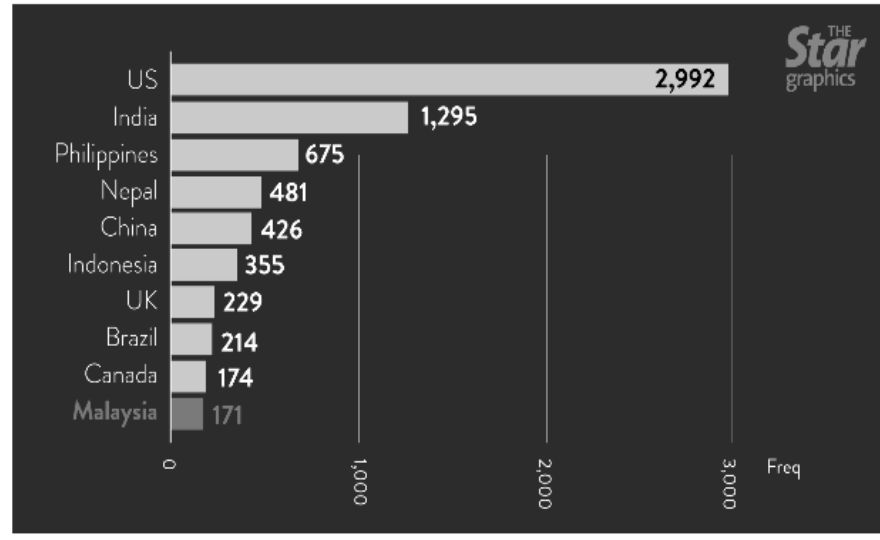

Fig. 2. Frequencies of landslides in 10 countries from 2007 to 2016. (Source: [46]).

\section{B. Flash Flood}

Flash floods cause high monetary losses and are related to development at either construction or operational stages. The severity of these problems has been an essential focus in Malaysia because it is related to terrain condition, amount of rain and human activities [20]. The primary source of runoff in a drainage catchment is rainfall. Sediment discharge is not caused solely by rain. It is also influenced by changes in land use due to human activities [47]. This sediment deposition which mostly comes from ill-controlled construction projects flows into rivers, causing the reduction in flow carrying capacity of the rivers. Soil erosion has also resulted in shallow riverbeds and water causeways, thus prompting flash floods in low-lying areas. The annual Klang River sediment deposition is approximately $250-550 \mathrm{~m}^{3} / \mathrm{km}^{2}$ tons [48]. Consequently, the upstream regions of Sungai Anak Ayer Batu catchment reach 50,000 tons $/ \mathrm{km}^{2} /$ year. Many rivers in Kuala Lumpur and Klang could not effectively function as a water conveyance two decades ago due to these high-sediment movements [49].

Over a decade ago (2006), Johor was affected by significant floods where more than 90,000 people were evacuated. In the same period, two Pahang districts (Pekan and Rompin) were also affected, and over 20,000 people were relocated to safer places. Prolonged high-intensity rainfall and land-use changes in Kuantan pose a severe threat to society, which may have caused them [20]. Zakaria et al. [50] stressed that urbanisation increases the construction areas that change the hydrologic and hydraulic characteristics of the catchments. Forest clearance, logging activities, farming, housing development and other human land-use activities are factors that have altered the hydrological parameters [49]. Therefore, a series of flash floods usually occur in an urban area with increasing severity yearly, as shown in Table III.

TABLE III: FLASH FLOODS IN MALAYSIA IN 1967-2020

\begin{tabular}{|c|c|c|c|c|}
\hline $\begin{array}{c}\text { Date of } \\
\text { Incident }\end{array}$ & Place & Type of Problems & $\begin{array}{l}\text { No. of } \\
\text { Death }\end{array}$ & Ref. \\
\hline 1967 & Bota, Perak & $\begin{array}{l}\text { The flood washed } \\
\text { away Bota Bridge }\end{array}$ & - & [51] \\
\hline Jan 1971 & Kuala Lumpur & Hit by flash floods & - & \\
\hline 1993 & $\begin{array}{c}\text { Cameron } \\
\text { Highland, } \\
\text { Pahang } \\
\end{array}$ & $\begin{array}{l}\text { Cameron highlands } \\
\text { mud flood }\end{array}$ & - & {$[52]$} \\
\hline Dec 1996 & $\begin{array}{l}\text { Keningau, } \\
\text { Sabah }\end{array}$ & $\begin{array}{c}\text { Floods brought by } \\
\text { Tropical Storm } \\
\text { Greg }\end{array}$ & 241 & \\
\hline Nov 2000 & $\begin{array}{l}\text { Kelantan, } \\
\text { Terengganu, } \\
\text { North Malaysia } \\
\text { and nearby } \\
\text { Southern } \\
\text { Thailand. }\end{array}$ & $\begin{array}{l}\text { Flood triggered by } \\
\text { heavy rainfall } \\
\text { caused } \\
\text { extensive property } \\
\text { damage and losses }\end{array}$ & 15 & [35] \\
\hline $\begin{array}{l}23 \text { Oct } \\
2003\end{array}$ & $\begin{array}{c}\text { State of } \\
\text { Penang, Kedah } \\
\text { and northern } \\
\text { Perak) }\end{array}$ & $\begin{array}{c}\text { Three days of } \\
\text { continuous rains } \\
\text { triggered } \\
\text { massive flooding in } \\
\text { Northern Malaysia }\end{array}$ & - & \\
\hline $\begin{array}{l}26 \text { Dec } \\
2004\end{array}$ & $\begin{array}{c}\text { States of } \\
\text { Penang, Kedah } \\
\text { and Perlis }\end{array}$ & Asian Tsunami & 68 & {$[52]$} \\
\hline $\begin{array}{c}2 \text { Mar } \\
2006 \\
\end{array}$ & Shah Alam & Hit by flash floods & - & \\
\hline $\begin{array}{c}\text { Dec } 2006 \\
\text { and } \\
\operatorname{Jan} 2007 \\
\end{array}$ & Johor & $\begin{array}{c}\text { Floods in Johor } \\
\text { State }\end{array}$ & 18 & \\
\hline $\begin{array}{c}\text { 10 June } \\
2007\end{array}$ & Kuala Lumpur & Hit by flash floods & - & \\
\hline Dec 2007 & $\begin{array}{c}\text { Kelantan, } \\
\text { Terengganu } \\
\text { Pahang, Johor }\end{array}$ & Hit by flash floods & - & \\
\hline 2008 & Johor & $\begin{array}{c}\text { Floods in Johor } \\
\text { State } \\
\end{array}$ & 28 & \\
\hline Nov 2010 & $\begin{array}{l}\text { Kedah and } \\
\text { Perlis }\end{array}$ & $\begin{array}{c}\text { Floods in Kedah } \\
\text { and Perlis due to } \\
\text { heavy rainfall after } \\
\text { a tropical } \\
\text { depression } \\
\end{array}$ & 4 & \\
\hline Jan 2011 & $\begin{array}{l}\text { State of Johor: } \\
\text { Segamat, Batu } \\
\text { Pahat, } \\
\text { Kluang and } \\
\text { Muar }\end{array}$ & $\begin{array}{l}\text { Flood due to heavy } \\
\text { rainfall } \\
\text { caused three of the } \\
\text { main rivers in } \\
\text { Johor (Sungai } \\
\text { Muar, Sungai } \\
\text { Benut and Sungai } \\
\text { Mengkibol) to } \\
\text { burst their bank }\end{array}$ & & [35] \\
\hline 2013 & $\begin{array}{c}\text { Pahang } \\
\text { Terengganu } \\
\end{array}$ & $\begin{array}{l}\text { Hit by flash floods, } \\
20000 \text { evacuated }\end{array}$ & - & \\
\hline Dec 2014 & $\begin{array}{c}\text { Kelantan, } \\
\text { Terengganu, } \\
\text { Pahang, Perak, } \\
\text { Perlis,Sabah } \\
\end{array}$ & Hit by flash floods & - & [52] \\
\hline $\begin{array}{c}20 \text { Oct } \\
2017\end{array}$ & $\begin{array}{c}\text { Jelapang, } \\
\text { Perak } \\
\end{array}$ & Floods & - & {$[51]$} \\
\hline $\begin{array}{l}12 \text { Nov } \\
2017\end{array}$ & Seremban & $\begin{array}{c}\text { Flash flood due to } \\
\text { clogged drainage } \\
\text { as unable to cope } \\
\text { heavy rain }\end{array}$ & - & [53] \\
\hline
\end{tabular}




\begin{tabular}{|c|c|c|c|c|}
\hline $\begin{array}{c}30 \mathrm{Nov} \\
2017\end{array}$ & $\begin{array}{c}\text { Taman } \\
\text { Selayang, } \\
\text { Kuala Lumpur }\end{array}$ & $\begin{array}{l}\text { Poor maintenance } \\
\text { of drainage. Due to } \\
\text { construction } \\
\text { site-aggravated the } \\
\text { clogged }\end{array}$ & - & [51] \\
\hline $\begin{array}{l}\text { 8 Sept } \\
2018\end{array}$ & $\begin{array}{l}\text { Georgetown, } \\
\text { Pulau Pinang }\end{array}$ & $\begin{array}{l}\text { Heavy raining from } \\
6 \text { am to } 10 \mathrm{am} \\
\text { caused flooding }\end{array}$ & - & [54] \\
\hline $\begin{array}{c}10 \text { Sept } \\
2020\end{array}$ & Kuala Lumpur & $\begin{array}{l}\text { Heavy rain caused } \\
\text { flooding around } \\
\text { Masjid Jamek }\end{array}$ & - & [55] \\
\hline
\end{tabular}

The rivers' capacity was considerably reduced due to siltation from exposed land development scheme erosion, rubbish dumping and river channel constriction. In Georgetown, Pulau Pinang, rapid development around the hillside was the primary contributing factor of flash flood risk [26]. Continued, uncontrolled soil erosion and failures of sediment control measures in several cases led to the deposition of the heavy load of silts, sediment, debris and gravel in flat ground areas where water flowed at a relatively low velocity [27]. Usamah [26] also found that sediment released from uncontrolled development and unpaved surfaces may narrow stream channels, blocking the natural course of the waterway, associated with an increased urban flash flood.

\section{COMPliance LeVel of Projects DeVelopers}

Based on EQPAEIAO2015, 38 types of proposed development projects are subjected to EIA scrutiny and reporting, especially those involving sensitive areas [56]. Development aspects and development legislation are several issues that need to be stressed on landslide and flash flood incidences [13], [57]. Chan [49] highlighted numerous policies, laws, legislation and EIA guidelines introduced by the Malaysian government to curb the adverse impact on the environment. However, the level of compliance and the effectiveness of mitigation measures still need improvement.

One glaring setback is the requirement of thresholds for sizes, areas and quantums before EIA could be deemed mandatory. Projects smaller than 50 ha do not require developers to carry out EIA. Perhaps, these difficulties could be faced by authorities, causing several hill site development projects are exempted from EIA [46]. The exploitation of hill land with steep to very steep slopes is currently in a state of concern as the demand for houses at elevated areas increases (development in Teluk Bahang, Tanjung Bungah and Paya Terubong) [58]. Thus, soil erosion, landslides, mudslides and flash floods on the lower ground frequently affect these areas [59].

The Penang Structure Plan 2007 (under the Town and Country Planning Act 1976) did not allow any development above a gradient of $25^{\circ}$ and 250 feet above sea level [59]. The lack of detailed impact studies on the progress at slopes poses a danger to the surroundings and people. Such event is included in the Second Schedule, requiring the public display of EIA report and proposals. Although the EIA justifies the impact within the developed areas, several effects are not localised and could affect the downstream and adjacent regions [60]. This issue has been discussed in detail by Chan [61] by focusing on hilly slope development.

\section{PREVENTING AdVERSE ENVIRONMENTAL IMPACTS}

Land-disturbing Pollution Prevention and Mitigation Measures (LD-P2M2) and Erosion and Sediment Control Plan 2010 (ESCP), introduced by the Department of Environment [2] and the Department of Irrigation and Drainage Malaysia [62], are preventive guidelines to avoid adverse environmental impacts such as landslide and flash flood. LD-P2M2 is defined as using construction methods, processes, materials and practices to prevent, reduce or eliminate the possible pollution sources throughout the protection, preservation and conservation of land with the best management practices and techniques [2].

ESCP should prevent problems and control erosion and siltation during the stages from land clearing to project completion, as stated in the Environmental Management Plan [2]. For hill slope development, areas with a high potential for landslides should be avoided. The contractor must ensure that all cut and fill slopes with appropriate drainage and vegetative cover such as turfing, terracing/benching and reinforced concrete wall, are stabilised immediately after construction. Land clearing activities should be planned to avoid reasonable heavy rainfall periods. Steep slopes should be regularly monitored for any sign of erosion or mass movement, and immediate remedial measures should be implemented if required [2], [63].

Flood management in Malaysia is more focused on structural measures and limited to environmental impacts of flood disasters. When a flood occurs, the depth of the water, the velocity of flows and the duration of inundation contribute to the relative severity of flood impacts [64]. All development must follow the guidelines provided such as those in the Urban Stormwater Management Manual (MSMA) [62] which stated that its function could classify stormwater quantity control facilities as detention facilities or retention facilities in development areas. The primary purpose of detention facilities is to reduce peak discharge through the temporary storage and gradual release of stormwater runoff via an outlet control structure or other release mechanisms. Retention facilities are commonly sized to reduce the volume of stormwater runoff generated from an urban area [62].

\section{CONCLUSION}

The availability of legal instruments to avoid environmental disaster risks, which is central to the requirement to carry out EIA, is investigated in this study. Despite these legal requirements, many incidences have occurred almost annually since a decade ago. Historical records have shown that landslide and floods cause monetary and human losses. The effectiveness of impact assessments in drawing the right prediction and relevant mitigation measures to reduce adverse impacts should be continuously improved. Soil erosion remains critical during construction and following completion or developments. Developers, contractors and agencies should cooperate to control soil erosion because it potentially causes disasters from landslides and flash floods secondary to their water bodies' flows. In conclusion, while the application of EIA is a preemptive measure to reduce the risk of environmental disasters related 
to project development, its current related legislation must be continuously strengthened to protect the environment effectively through EIA processes.

\section{CONFLICT OF INTEREST}

The authors declare no conflict of interest.

\section{AUTHOR CONTRIBUTIONS}

"Conceptualization, Nor Azam and Muhammad Rizal; Validation, Nor Azam and Muhammad Rizal; Resources, Nor Azam, Syabiha and Amni Umirah; Data curation, Syabiha and Amni Umirah; Writing-original draft preparation, Syabiha and Amni Umirah; Writing-review and editing, Nor Azam, Muhammad Rizal, Syabiha, Amni Umirah, Nazatul Syadia, and Wesam; Visualization, Nor Azam, Muhammad Rizal, Syabiha, Amni Umirah, Nazatul Syadia, and Wesam; Supervision, Nor Azam Ramli and Muhammad Rizal; Project administration, Nor Azam Ramli; funded by Nor Azam Ramli, Syabiha, Amni Umirah and Nazatul Syadia. All authors have read and agreed to the published version of the manuscript."

\section{REFERENCES}

[1] P. Wathern, Environmental Impact Assessment - Theory and Practice, Unwin Hyman Ltd, United Kingdom, 1988.

[2] DOE (Department of Environment), "Environmental impact assessment guidelines in Malaysia," Ministry of Natural Resources and Environment, 2016.

[3] A. R. Mahmud, Z. Sakawi, and K. N. A. Maulud, "Analisa Terhadap kaedah pengulasan laporan penilaian impak alam sekeliling (EIA) di Malaysia," Geografia Malaysian Journal of Society and Space, 2017, vol. 13, no. 4, pp. 11-21.

[4] M. S. Samsurijan et al., "Land use change in Kelantan: a review of the environmental impact assessment (EIA) reports," Geografia Malaysian Journal of Society and Space, 2018, vol. 14, no. 4, pp. 322-331.

[5] A. Awang et al., "Development, environmental degradation and environmental management in Malaysia," European Journal of Social Sciences, 2009, vol. 9, no. 2, pp. 257-264.

[6] F. Ahmad et al., "Environmental risk assessment on hill site development in Penang, Malaysia: recommendations on the management system," European Journal of Scientific Research, 2010, vol. 40, no. 3, pp. 318-340.

[7] S. E. Mauro, "Environmental degradation," The International Encyclopedia of Geography, John Wiley \& Sons, Ltd, 2017, DOI: 10.1002/9781118786352.wbieg1068.

[8] C. J. Barrow, Environmental Management for Sustainable Development, 2nd Edition Routledge Introductions to Environment, Taylors and Francis, 2016.

[9] A. B. Hapuarachchi, K. Hughey, and H. Rennie, "Effectiveness of environmental impact assessment (EIA) in addressing development-induced disasters: A comparison of the EIA processes of Sri Lanka and New Zealand," Natural Hazards, 2016, vol. 81, no. 1, pp. 423-445.

[10] UNISDR. United Nation Office for Disaster Risk Reduction. Implementation of the HFA: 2007-2013, UNISDR. 2014. [Online]. Available:

http://www.preventionweb.net/files/32916implementationofthehyogoframeworkfo.pdf

[11] K. W. Tan and M. Mokhtar, "An appropriate institutional framework towards integrated water resources management in Pahang River Basin, Malaysia," European Journal of Scientific Research, 2009, vol. 27, no. 4, pp. 536-547.

[12] K. N. Othman, A. Alias, and N. H. Ali, "Property development prospect on high land and steep slope areas-a case study in Bukit Antarabangsa, State of Selangor," in Proc. Asian Conference of Real Estate 2011, Johor, 2011.

[13] K. N. Othman, A. Alias, N. Ali, and I. Muhamad, "Re-examining the Control mechanism for sustainable property development on Highland areas: A case of Malaysia," European Journal of Sustainable Development, 2014, vol. 3, no. 4, pp. 219-230.
[14] A. Alias, A. S. Ali, and K. N. Othman, "Land Development on high land areas: Comparison of process implementation and legislation effectiveness between Malaysia and Hong Kong," World Journal of Engineering and Technology, 2014, vol. 02, no. 03, pp. 55-60.

[15] R. M. Khalid, S. A. Rahman, and M. B. Mokhtar, "Legal perspective on development policies for sustainability of water in Malaysia," Sustainable Development, 2013, vol. 21, no. 3, pp. 144-151.

[16] DOE (Department of Environment), Handbook of Environmental Impact Assessment in Malaysia, Ministry of Natural Resources and Environment, 2007.

[17] C. H. Abdullah et al., "Development of slope management in Malaysia," International Forum on Landslide Disaster Management, 2007, pp. 3-16.

[18] S. S. Gue and S. Y. Wong, "Slope engineering design and construction practice in Malaysia," CIE-IEM Joint Seminar on Geotechnical Engineering, 2009, Yilan, Taiwan.

[19] P. Blaikie, Brookfield H. Land Degradation and Society, London: Methuen, 1987, p. 296

[20] H. A. Rahman, "An overview of environmental disaster in Malaysia and preparedness strategies," Iranian Journal of Public Health, 2014, vol. 43, suppl. 3, pp. 17-24.

[21] D. Kazmi et al., "A study on the contributing factors of major landslides in Malaysia," Journal of Civil Eng, 2016, vol. 2, no. 12, pp. 669-678.

[22] S. Murakami et al., "Landslides Hazard map in Malay peninsula by using historical landslide database and related information," Journal of Civil Engineering Research, 2014, vol. 4, no. 3A, pp. 54-58.

[23] Y. C. R. Tse, "The implementation of EMS in construction firms: a case study in Hong Kong," Journal of Environmental Assessment Policy and Management, 2001, vol. 3, no. 2, pp. 177-194.

[24] G. Ding and C. Langston, "Multiple criteria sustainability modelling: A case study on school buildings," International Journal of Construction Management, 2004, vol. 4, no. 2, pp. 13-26.

[25] A. Griffith, P. Stephenson, and K. Bhutto, "An integrated management system for construction quality, safety and environment: A framework for IMS," International Journal of Construction Management, 2005 , vol. 5, no. 2 , pp. 51-60.

[26] M. Usamah, "Analysis of causal and trigger factors of the August 2017 landslide in Freetown, Sierra Leone: Towards a sustainable landslide risk management in Sierra Leone," Technical Publication, UNDP Sierra Leone and Environmental Protection Agency, Freetown, 2017.

[27] Y. Alimohammadlou, A. Najafi, and A. Yalcin, "Landslide process and impacts: A proposed classification method," CATENA104 (May 2013), 2013, pp. 219-232.

[28] J. K. Raj, "Landslide in the Granitic bedrock areas of humid Peninsular Malaysia," in Proc. Malaysia-Japan Symposium on Geohazards and Geoenvironmental Engineering-Recent Advances, Bangi, Malaysia, 2004, pp. 101-106.

[29] I. A. R. Al-Hadu et al., "Multi-criteria analysis in environmental management: selecting the best stormwater erosion and sediment control measure in Malaysian construction sites," Energy and Environment, 2011, vol. 2, no. 5, pp. 853-862.

[30] K. H. Bujang et al., Landslides in Malaysia: Occurrences, Assessment, Analyses and Remediation, Universiti Putra Malaysia Press, Serdang, Selangor, 2008.

[31] M. R. U. Mustafa et al., "Land-use Assessment and its influence on the spatial distribution of rainfall erosivity: A case study of Cameron Highlands Malaysia,” Journal of Ecological Engineering, 2019, vol. 20, no. 2, pp. 183-190.

[32] H. A. Rahman and J. Mapjabil, "Landslides disaster in Malaysia: An overview," Health and the Environment Journal, 2017, vol. 8, no. 1, pp. 58-71.

[33] Astro Awani Online. (2015). Landslide incidents in Karak from 1985-2015. [Online]. Available: http://english.astroawani.com/malaysia-news/landslide-incidents-kara k-1985-2015-80564

[34] S. Qasim et al., "Causal factors of Malaysian landslides: A narrative study," Research Journal of Applied Sciences, Engineering and Technology, 2013, vol. 5, no. 7, pp. 2303-2308.

[35] E. M. A. Zawawi, N. S. Yusof, and Z. Ismail, "Adoption of post-disaster waste management plan into disaster management guidelines for Malaysia," Journal of Material Cycles and Waste Management, 2018, vol. 20, no. 1, pp. 223-236.

[36] (2016). Earth-chronicles, Landslide in Malaysia by space. [Online]. Available:

http://earth-chronicles.com/natural-catastrophe/landslide-in-malaysia. html 
[37] (2016). The Stars Online, Sunday's landslides, floods at Tanah Rata due to 'abnormal rainfall'. [Online]. Available: https://www.thestar.com.my/news/nation/2016/12/28/sunday-tanah-ra ta-landslide-due-to-abnormalrainfall/

[38] The Stars Online, Tanjung Bungah landslide: Malaysian among those trapped. (2017). [Online]. Available: https://www.thestar.com.my/news/nation/2017/10/21/tanjung-bungahlandslide-malaysian-victim-among-those-trapped/

[39] (2018). The Stars Online, Road near Genting Highlands caves in. [Online]. Available: https://www.thestar.com.my/news/nation/2018/04/07/genting-highlan ds-road-partially-closed-due-to-landslide/

[40] (2018). The Stars Online, Bukit Kukus road project had no EIA report. [Online]. Available: https://www.thestar.com.my/news/nation/2018/11/14/bukit-kukus-roa d-project-had-no-eia-report/\#5pxdWT7R4J0xzHhX.99

[41] M. S. Aini, A. Fakhru'l-Razi, and M. Daud, "Evolution of emergency management in Malaysia," Journal of Contingencies and Crisis Management, 2001, vol. 9, no. 1, pp. 46-53.

[42] G. S. Sew and T. Y. Chin, "Mitigating the risk of a landslide on hill-site development in Malaysia," in Proc. the 2nd World Engineering Congress, Sarawak, Malaysia, July 22-25, 2002, pp. 1-10.

[43] N. Mahyudin and S. P. Rao, "Integration of Environmental sustainability issues in the teaching of the built environment in Malaysian universities," in Proc. First International Conference on Environment Research and Assessment, Bucharest, Romania, 2003, 23-27.

[44] J. C. Phuoc, "Hill slope construction and development guidelines: A strategic comparative analysis between the State of Selangor guideline (GPPPNS 2010) and Kuala Lumpur Guideline (GPWPKL 2010)," in Proc. Special Issue for the International Symposium on Multi-Hazard and Risk 2015 (ISMHR 2015), Universiti Teknologi Malaysia (UTM), Kuala Lumpur, Malaysia, March 23-24, 2015, pp. 127-143.

[45] A. Derwaman. (2018). Bukit Kukus landslide: An obvious case of wilful negligence the New Malaysia must not ignore. [Online] Available:

https://www.nst.com.my/news/nation/2018/10/424926/bukit-kukus-la ndslide-obvious-case-wilful-negligence-new-malaysia-must

[46] (2018). The Star Online, Malaysia among countries especially prone to landslides. [Online]. Available: https://www.thestar.com.my/news/nation/2018/12/04/msia-ranks-high ly-for-landslides-country-experienced-185-occurrences-annually-in-p ast-10-years/

[47] W. R. Ismail and M. Hashim, "Changing rainfall and sediment fluxes in the Kinta river catchment, Malaysia," in Proc. the International Association of Hydrological Sciences, 2015, vol. 367, pp. 340-345.

[48] K. S. Low and V. Balamurugan, "Urbanization and urban water problems in Southeast Asia: A case of unsustainable development," Journal of Environmental Management, 1991, vol. 32, pp. 195-209.

[49] N. W. Chan, "Responding to landslide hazards in rapidly developing Malaysia: A case of economics versus environmental protection," Disaster Prevention and Management: An International Journal, 1998 vol. 7, no. 1, pp. 14-27.

[50] N. A. Zakaria et al. (2004). MSMA, a new urban stormwater management manual for Malaysia. [Online]. Available: redac. eng. usm. $\mathrm{my} / \mathrm{html} / \mathrm{publish} / 2004 \_06 . P d f$

[51] Yeap and Loh. (2017). Clogged drains main cause of floods. The Stars Online. [Online]. Available: https://www.thestar.com.my/metro/metro-news/2017/10/20/clogged-d rains-main-cause-of-floods-city-council-looking-at-overall-drainage-s ystem-in-jelapang-to-a/

[52] N. W. Chan, "Managing urban rivers and water quality in Malaysia for sustainable water resources," International Journal of Water Resources Development, 2012, vol. 28, no. 2, pp. 343-354.

[53] Bernama. (2017). Flash floods in Seremban due to clogged drains, says MB. [Online]. Available: https://www.malaymail.com/s/1508687/flash-floods-in-seremban-dueto-clogged-drains-says-mb

[54] (2018). The Stars Online, Penang hit by flash floods. [Online]. Available:

https://www.thestar.com.my/news/nation/2018/09/08/penang-hit-by-fl ash-floods-many-late-for-work-due-to-swamped-roads-after-heavy-rai $\mathrm{n} /$

[55] (2020). BH Harian, Banjir di ibu kota selepas hujan lebat 2 jam. [Online].

Available: https://www.bharian.com.my/berita/nasional/2020/09/729992/banjir-d i-ibu-kota-selepas-hujan-lebat-2-jam
[56] DOE (Department of Environment), "Environmental quality (prescribed activities) environmental impact assessment order 2015," Ministry of Natural Resources and Environment, 2015.

[57] I. M. Yusoff et al., "Exploring the managing of flood disaster: A Malaysian perspective," Geografia-Malaysian Journal of Society and Space, 2018, vol. 14, no. 3 .

[58] Bernama. (2018). Engineer: Lives at risk in Penang Hill project. [Online]. Available: https://www.freemalaysiatoday.com/category/nation/2018/04/29/engi neer-lives-at-risk-in-penang-hill-project/

[59] (2018). The Malaysian Times, 10 to 12 people feared buried in Penang landslides. [Online]. Available: http://www.themalaysiantimes.com.my/10-to-12-people-feared-buried -in-penang-landslide/

[60] (2018). New Straits Times, Slam brakes on Penang Hill Hotel projects, govt urged. [Online]. Available: https://www.nst.com.my/news/nation/2018/11/429593/slam-brakes-pe nang-hill-hotel-projects-govt-urged

[61] N. W. Chan, "Environmental hazards associated with hill land development in Penang Island, Malaysia: some recommendations on effective management," Disaster Prevention and Management: An International Journal, 1998, vol. 7, no. 4, pp. 305-318.

[62] DID (Department of Irrigation and Drainage), Urban Stormwater Management Manual for Malaysia, Government of Malaysia, 2010.

[63] DOE (Department of Environment), Ministry of Science, Technology and Environment Malaysia, Guideline for Prevention and Control of Soil Erosion and Siltation in Malaysia, ISBN: 983-9119-58-3, 1996.

[64] L. C. Chang et al., "Building ANN-based regional multi-step-ahead flood inundation forecast models," Water, 2018, vol. 10, no. 9, p. 1283.

Copyright $\odot 2021$ by the authors. This is an open access article distributed under the Creative Commons Attribution License which permits unrestricted use, distribution, and reproduction in any medium, provided the original work is properly cited (CC BY 4.0).

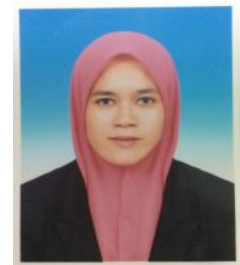

Syabiha Shith graduated with her bachelor of civil engineering from Universiti Sains Malaysia (USM) in 2012. She received her master of science in environmental engineering (2013) and $\mathrm{PhD}$ in air quality studies (2017) from USM. Before that, she worked as a post-doctoral fellow (2018-2019) at the USM under Environmental Assessment Clean Air Research, School of Civil Engineering.

Her research area was air quality studies (outdoor particulate matter and ozone transformation). She works on experimental and theoretical research in those areas and currently working on environmental impact assessment on historical cases of landslides and flash floods in Malaysia.

She joined the Department of Civil Engineering Technology, Faculty of Engineering and Built Environment, at Lincoln University College in 2019 She is currently working on a collaboration project with other universities and industries on indoor air pollution.

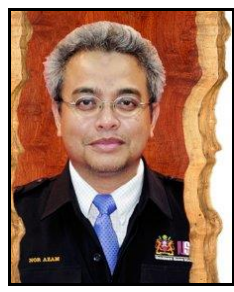

Nor Azam Ramli is a professor at the EACAR School of Civil Engineering, Universiti Sains Malaysia (USM), Malaysia. He went to university in Aberystwyth, Wales, to read his $\mathrm{PhD}$. He has 25 years of research experience in various $R \& D$ and consultancy projects related to air pollution and environmental impact assessment (EIA) areas, with publications in various national and international journals and books.

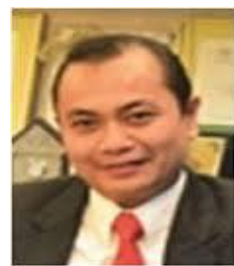

Muhammad Rizal Razman was born in Kajang, Selangor, Malaysia on 24th of May 1971. He obtained his bachelor of laws (LL.B.) (Hons.) in 1995 from Universiti Kebangsaan Malaysia. Meanwhile, he received his master of laws (LL.M.) (environmental law and management) in 1997 from the University of Wales, Aberystwyth, United Kingdom. He was conferred a doctor of philosophy $(\mathrm{PhD})$ (environment and development) from Universiti Kebangsaan Malaysia in 2009. He also has been registered since 1998 as a professional Advocate and Solicitor of the High Court (Malaya) by the Kuala Lumpur High Court.

$\mathrm{He}$ is a professor of environmental law and management at the Institute for Environment and Development (LESTARI), Universiti Kebangsaan Malaysia (UKM). He specialises in environmental law and management. His current research interests are governance for sustainability towards environmental justice, environmental sustainability based on law and 
management approaches, and environmental sustainability in health and technology-related studies.

Prof. Razman also serves on the editorial board of Malaysian Journal of Environmental Management: Incorporating The Asia-Pacific Region (MJEM), Malaysian Consumer Law Journal (MCLJ) and Asian Journal of Environment, History and Heritage (AJEHH). He also served on the international conferences' executive committees (such as International Symposium on Environment and Natural Resources; International Conference on Human Habitat and Environmental Change; International Conference on Consumer Law and Consumerism; Regional Seminar on Environmental Management) and many technical committees.

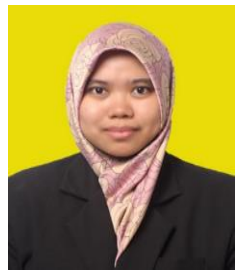

Amni Umirah Mohamad Nazir graduated with her bachelor of civil engineering from Universiti Sains Malaysia (USM) in 2017. She received her master of science in civil engineering for environmental and air quality study (2018) from USM. Currently, she is a second-year $\mathrm{PhD}$ student at Universiti Malaysia Kelantan (UMK).

Her research area was air quality studies (indoor air quality and ozone transformation), Environmental Impact Assessment (EIA) and Environmental Management Plan (EMP). She works on experimental and theoretical research in the areas. Now, she is working on nighttime ground-level ozone and environmental management plan in reducing the upkeep ozone concentration. She also a member of the Environmental Management Society (EMS) of Malaysia.

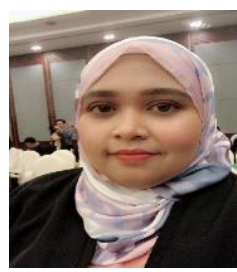

Nazatul Syadia Zainordin is a senior lecturer at Department of Environment, Faculty of Forestry and Environment, Universiti Putra Malaysia. Her field of research focuses mainly on air quality management and environmental impact assessment. She has been associated with various research grants related to air quality studies for the outdoor and indoor environment as a project investigator and co-researcher of the projects. She has experience working together with other researchers on projects related to prediction model of ground-level ozone; indoor air quality and thermal comfort in mosque buildings; and walkability assessment on the pedestrian facilities as an initiative to encourage active mode among schoolchildren, etc.

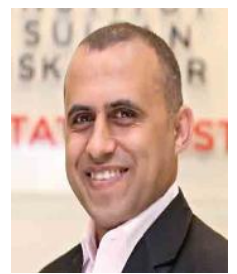

Wesam Al-Madhoun is holding a BSc in civil engineering from Palestine, MSc in environmental engineering-environmental impact assessment and a $\mathrm{PhD}$ in environmental engineering-air quality monitoring and modelling from Universiti Sains Malaysia (USM)

He has 15 years of working experience (teaching, training, research and consultancy), where he had

assignments in Palestine, Malaysia, Brunei, India, Indonesia, South Korea, USA and Canada.

He was a research fellow at the School of Civil Engineering, USM, He did a postdoctoral fellowship at Malaysia Japan International Institute of Technology (MJIIT), and he achieved A fellowship at the MIT-UTM Malaysia Sustainable Cities Program. He was a visiting scholar at the University of Seoul, University of Windsor and at Malaysia-Japan International Institute of Technology (MJIIT).

In terms of publications, he has more than 50 papers published at international peer-reviewed journals and conferences.

Currently, He is lecturing at Universiti Tun Hussein Onn Malaysia and leading a global initiative "Ambassadors of Sustainability" which include 6800 members from 100 countries. 